\title{
GPAT3 wt Allele
}

National Cancer Institute

\section{Source}

National Cancer Institute. GPAT3 wt Allele. NCI Thesaurus. Code C157047.

Human GPAT 3 wild-type allele is located in the vicinity of $4 \mathrm{q} 21.23$ and is approximately 70

$\mathrm{kb}$ in length. This allele, which encodes glycerol-3-phosphate acyltransferase 3 protein, plays a role in glycerolipid biosynthesis. 